\title{
IRRIGATION MANAGEMENT OF PEPPER CROP UNDER SURFACE AND SUB-SURFACE DRIP IRRIGATION SYSTEMS BY USING EXPERT SYSTEM, IRRIMET AND CROPWAT
}

\author{
Abousrie A. Farag*
}

\section{ABSTRACT}

The scarcity of water in Egypt need for hard work to solve it. One of the best solutions is good management of limited water, therefore, this paper aims to provide farmers and decision-makers with a new accurate and cheap technique for water management. The experimental work was carried out in the farm of Faculty of Agriculture, Benha University $\left(30^{\circ} 21^{\prime}\right.$ $26.24^{\prime \prime} N$ and $31^{\circ} 13^{\prime} 15.89^{\prime \prime}$ E) during the summer seasons of 2016 and 2017. Three irrigation management tools (Expert system (ES), IRRIMET model (IM) and Cropwat model $(\mathrm{CW})$ ) were applied with surface and subsurface drip irrigation systems. The results showed that the highest values of water saving were achieved by IM model followed by ES tool. Also, the estimated values of reference evapotranspiration (ETo), single crop factor $(K c)$ and crop evapotranspiration $\left(E T_{C}\right)$ under $E S$ were very close to that obtained under IM model while under $C W$ model the corresponding values were far from that under IM model especially the ETc values. Yield were achieved under subsurface drip irrigation system (SSDI). On the other hand, the IM model gave the highest values of pepper yield, water productivity (WP) and nutrient use efficiency (NUE) $\left(6.86\right.$ ton $\mathrm{h}^{-1}, 1.59 \mathrm{~kg}$ $\mathrm{m}^{-3}$ and $21.17 \mathrm{~kg} \mathrm{~kg}^{-1}$, respectively, with SSDI and 6.71 ton $\mathrm{h}^{-1}, 1.64 \mathrm{~kg} \mathrm{~m}^{-}$ ${ }^{3}$ and $20.75 \mathrm{~kg} \mathrm{~kg}^{-1}$, respectively, with SDI), followed by ES (6.02 ton $\mathrm{h}^{-1}$, $1.3 \mathrm{~kg} \mathrm{~m}^{-3}$ and $17.28 \mathrm{~kg} \mathrm{~kg}^{-1}$, respectively with SSDI and 4.31 ton $\mathrm{h}^{-1}, 1.09$ $\mathrm{kg} \mathrm{m}^{-3}$ and $13.76 \mathrm{~kg} \mathrm{~kg}^{-1}$, respectively with SDI. However, the differences between the values resulted from using ES and IM were not significant. The lowest values of pepper yield, WP and NUE were achieved with the management based on $C W$ model outputs.

Keywords: Cropwat, Expert systems, IRRIMET model, surface drip irrigation, subsurface drip irrigation, WUE and NUE.

\footnotetext{
* Lecturer at department of Agricultural and Bio-systems Engineering, Faculty of Agriculture, Benha University, Egypt. abousrie.ahmad@ fagr.bu.edu.eg
} 


\section{INTRODUCTION}

hortage of water is considered the most important problem that many countries are facing (Gohar and Ward, 2013). Water management and use are a continuing problem in developing countries with semiarid to arid climates such as Egypt. The lack of effective irrigation management is often the most limiting factor in increasing agricultural productivity in these countries (Walters and Jha, 2016).

The total amount of available water in Egypt is 55.5 milliard $\mathrm{m}^{3} /$ year and the sector of agriculture consumes about $85 \%$ of the total available water (Seleym and Elshafei, 2017). This amount of water may be decreased by $10 \%$ and $20 \%$ annually, reducing the national income of farmers by $32 \%$ to $33 \%$ per year (Gohar and Ward, 2013). Many studies recommended better management of water resources as one of the most important ways for decreasing the losses of water (Brouwer and Heibloem, 1986).

Due to the recognized loss of water caused by the error in predicting or calculating crop water requirements, many tools (models) are being used, nowadays (Al-Najar, 2011) for irrigation schedule or management, which is the most important key for succeeding any farm and to save irrigation water. Adjusting crop factors facilitates irrigation scheduling and helps achieving full yield potential without over-irrigation (Bryla et al., 2010). But effective use of water and soil in complex systems, such as irrigation areas, requires the management of large amounts of information and forecasting / decision-making algorithms in an uncertain environment (Mundo et al., 1970) and some models have been used for this purpose. According to Grosan and Abraham (2011), the rule-based systems, also known as production systems or expert systems, simulate the thinking of the human expert in solving an intensive knowledge problem. Cropwat model is used in many countries to estimate irrigation water requirements. Al-Najar (2011) claims that the accuracy of this model in calculating the reference evapotranspiration accounts for $\pm 5 \mathrm{~mm}$ /year.

The aim of this paper is to select the tools (models) for irrigation management of pepper crop by applying the expert system (ES) (Farag, 2012), Cropwat model (CW) and IRRIMET model (IM) either using local records or historical records and comparing not only the outputs used for 
irrigation scheduling in different subplots but also the resulted yields, water productivity, (WP) and nutrient use efficiency (NUE) as defined later. Using historical records could save costs and one of the aims is to evaluate impacts of this practice.

\section{MATERIALS AND METHODS}

\section{The experimental site}

The experimental site at Faculty of Agriculture, Moshtohor, Benha University has an iMETOS meteorological station, which is located on the faculty's farm located at latitude $30^{\circ} 21^{\prime} 26.24^{\prime \prime}$ and longitude $31^{\circ} 13^{\prime}$ $15.89^{\prime \prime}$, about $15 \mathrm{~m}$ above sea level. The experimental work was conducted at that farm, during the summer seasons of 2016 and 2017. The climate of this area is arid, and has arid climate (BWh) according to Köppen (1936). The investigated soil was characterized by a clayey texture with the following properties, respectively for the three layers 0-20, 20-40 and 40$60 \mathrm{~cm}$ : $\mathrm{pH}$ of 7.42, 7.19 and 77, EC of 2.59, 2.22 and $3.63 \mathrm{dS} \mathrm{m}^{-1}$, soil water content at saturation of $0.70,0.80$ and $0.77 \mathrm{~m}^{3} \mathrm{~m}^{-3}$, soil water content at field capacity of $0.335,0.385$ and 0.368 , soil water content at wilting point of $0.160,0.185$ and $0.177 \mathrm{~m}^{3} \mathrm{~m}^{-3}$ and bulk density of $1.10,1.15$ and $1.19 \mathrm{~kg} \mathrm{~m}^{-3}$. The average value of saturated hydraulic conductivity of the soil was $1.4 \mathrm{~m} \mathrm{day}^{-1}$.

Capsicum annuиm species (pepper) was used for this experiment; it belongs to the Solanaceous family and is usually divided into two groups, pungent and non-pungent, also called hot and sweet pepper (Zayed et al., 2013). The hot type was selected for this experiment Capsicum annuum 'Anaheim'. The experimental design was RCBD with three replicates.

Two irrigation systems: surface and sub-surface drip irrigation systems were used.

\section{Irrigation models}

The expert system (ES) was designed by Farag (2012). It can provide the user and decision maker the suitable decision in the field of fertilizers and water management. This system consists of database, user interface and rules processing unit (Fig. 1).

Cropwat model $(\mathrm{CW})$ is considered the most well spread program for irrigation management of annual crops (Smith, 1992); Even though FAOCropWat model is used for many countries to estimate irrigation water 
requirements (Al-Najar, H., 2011). It includes three sub models to estimate reference evapotranspiration $\left(E T_{o}\right)$, root depth and crop coefficients.

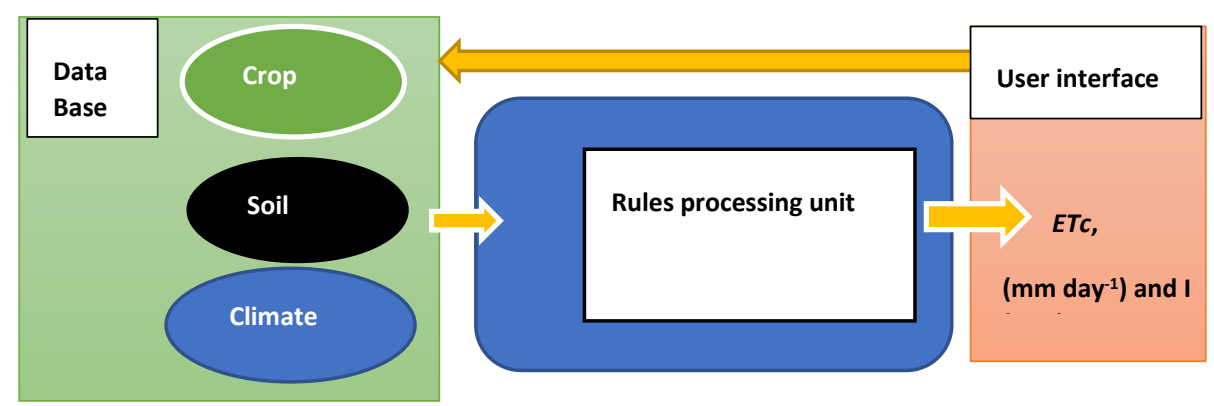

Fig (1). The expert system components

IRRIMET (IM) is a new program included in the website of FieldClimate platform (https://www.fieldclimate.com/) which works with iMETOS stations. The daily meteorological data are measured by iMETOS, which has sensors for air temperature, relative humidity, rain, leaf wetness, soil temperature, radiation, wind speed and wind direction. IRRIMET is a free web application associated with the FieldClimate platform, for the calculation of the daily soil water balance. For this aim, it takes into account the precipitation, irrigation depths and crop evapotranspiration for wellwatered plants $\left(E T_{c}\right)$ and presents the results in tables and graphics. The value of the reference evapotranspiration $\left(E T_{o}\right)$ is calculated from the local microclimatic data recorded by the station (Domínguez and SainzAguirre, 2016).

\section{Crop water requirements}

The crop water requirements were calculated by those three different tools: Expert system (ES), IRRIMET Model (IM) and CropWat model (CW), but based on different data.

The IRRIMET model has the same strategy of ES and CW, but the main difference among them was that daily required meteorological data from iMETOS were used for the IM model. Daily values for $E T_{o}$ and $E T_{c}$ were calculated by IRRIMET program.

All the investigated models used the same equation to estimate ETo but only IM used daily data. CW and ES used monthly historical records from different origins (the average of last 10 years). 
$E T_{o}$ was calculated with Penman-Monteith equation (eq. 1) according to Allen et al., 1998.

$$
E T_{o}=\frac{0.408 \Delta\left(R_{n}-G\right)+\gamma \frac{900}{T+273} U_{2}\left(e_{s}-e_{a}\right)}{\Delta+\gamma\left[1+0.34 U_{2}\right]}
$$

where $E T_{O}$ is reference evapotranspiration $\left[\mathrm{mm} \mathrm{day}^{-1}\right], R_{n}$ net radiation above the crop surface $\left[\mathrm{MJ} \mathrm{m}{ }^{-2} \mathrm{day}^{-1}\right], G$ soil heat flux density $\left[\mathrm{MJ} \mathrm{m}^{-2}\right.$ day $\left.{ }^{-1}\right], T$ mean daily air temperature at $2 \mathrm{~m}$ height $\left[{ }^{\circ} \mathrm{C}\right], U_{2}$ wind speed at $2 \mathrm{~m}$ height $\left[\mathrm{m} \mathrm{s}^{-1}\right]$, es saturation vapor pressure $[\mathrm{kPa}], e_{a}$ actual vapor pressure $[\mathrm{kPa}], e_{s}-e_{a}$ saturation vapor pressure deficit $[\mathrm{kPa}], \Delta$ slope vapor pressure curve $\left[\mathrm{kPa}{ }^{\circ} \mathrm{C}^{-1}\right]$ and $\gamma$ psychometric constant $\left[\mathrm{kPa}^{\circ} \mathrm{C}^{-1}\right]$.

Single crop coefficients $\left(K_{c}\right)$ were added to IRRIMET application taken from FAO table (Allen et al., 1998). The $K c$ values taken for pepper crop were 0.6 in the initial stage, 1.05 in mid stage and 0.9 in late stage. The growth periods were 30, 35, 40 and 20 days for initial, mid and late stages, respectively (Allen et al., 1998).

$$
E T_{c}=E T_{o} . K_{c}
$$

where $E T_{C}$ is crop evapotranspiration $\left(\mathrm{mm} \mathrm{day}^{-1}\right)$ and $E T_{O}$ is reference evapotranspiration $\left(\mathrm{mm} \mathrm{day}^{-1}\right)$.

ES tool has the same strategy as IM and CW in calculating $E T_{C}$, but there were differences among them in estimating the adjusted crop coefficients ( $K_{c \text { adj }}$, equations 3 and 4$)$.

$K \boldsymbol{c}_{\boldsymbol{m i d} \boldsymbol{A d j}}$ is the adjusted crop coefficient at mid growth stage calculated from equation (4) according to Allen et al. (1998):

$$
\mathrm{Kc}_{\text {mid Adj }}=\mathrm{Kc} c_{\text {mid(table })}+\left[0.04\left(\mathrm{U}_{2}-2\right)-0.004\left(\mathrm{RH}_{\min }-45\right)\right]\left(\mathrm{h}_{\mathrm{p}} / 3\right)^{0.3}[3]
$$

where $\boldsymbol{K} \boldsymbol{c}_{\boldsymbol{m i d}(\boldsymbol{t a b l e})}$ is taken from FAO 56 (Allen $\boldsymbol{e t} \boldsymbol{a l . ,}$ 1998), $\mathrm{h}_{\mathrm{p}}$ is the maximum plant height $(\mathrm{m}), R H_{\text {min }}$ the mean value for minimum daily 
relative humidity during the mid-season [\%] and $U_{2}$ is the value of wind speed at $2 \mathrm{~m}$ height during the mid-season $\left[\mathrm{m} \mathrm{s}^{-1}\right]$.

$\boldsymbol{K} \boldsymbol{c}_{\text {end } \boldsymbol{A d j}}$ is the adjusted crop coefficient at the end of the growth stage, which is estimated from equation (5), according to Allen et al. (1998):

$$
K \mathrm{c}_{\text {end Adj }}=K c_{\text {end(table })}+\left[0.04\left(U_{2}-2\right)-0.004\left(R H_{\text {min }}-45\right)\right]\left(h_{\mathrm{p}} / 3\right)^{0.3}[4]
$$

where $\boldsymbol{K} \boldsymbol{c}_{\text {end }(\boldsymbol{t a b l e})}$ is the crop coefficient at the end of the growth stage, taken from FAO56 tables (Allen et al., 1989).

$K c_{d e v}$ is the crop coefficient during the days of the development growth stage c, calculated by equation (5) according to Farag (2012):

$$
K c_{\text {dev }}=A+(B * X)
$$

where

$$
A=K c_{\text {int }}-\left(B * I_{S}\right)
$$

where $I_{\mathrm{S}}$ is the number of days of initial stage (day),

$$
B=\frac{K c_{\text {mid } A d j}-K c_{\text {int }}}{\text { Dev stage }}
$$

\section{Root depth measured and modelled}

The root depth was predicted by the three models: in ES model according to Borg and Grimes (1986) by equation (8):

$$
Z_{r}=Z_{r m}\left[0.511+0.511 \operatorname{Sin}_{(\mathrm{rad})}\left[3.03 \frac{D A P}{D T M}-1.47\right]\right][8]
$$

where $Z_{r}$ is the root depth and $D A P$ is the number of days after planting, $Z_{r m}$

is the maximum root depth $(0.75 \mathrm{~m})$ and $D T M$ is the maximum days to maximum root depth (70), where the parameters $Z_{r m}$ and DTM were taken from Allen et al. (1998). 
With the model IM, the root depth was considered constant from the beginning until harvest, equal to $35 \mathrm{~cm}$.

With the $C W$ model, $Z_{r m}$ was considered $0.75 \mathrm{~m}$ (as above) and the root depth changed linearly from $0.25 \mathrm{~m}$, at the beginning of the growth season until that maximum value, at mid stage, simulated by the model as shown in Results.

Conversely, the root of pepper crop was measured six times, during the growth season, by excavation method in each of treatment (with three replications).

\section{Irrigation scheduling}

The total available soil water $(T A W)$ in a layer corresponding to average $\mathrm{Zr}$ was calculated according to:

$$
T A W=1000\left(\theta_{f c}-\theta_{w p}\right) Z_{r}
$$

where $T A W$ is the total available soil water in the root zone $(\mathrm{mm}), \theta_{f c}$ is the water content at field capacity $\left(\mathrm{m}^{3} \mathrm{~m}^{-3}\right), \theta_{w p}$ is the water content at wilting point $\left(\mathrm{m}^{3} \mathrm{~m}^{-3}\right)$ and $\mathrm{Zr}$ is the root depth (m).

The readily available water $(R A W)$ was calculated according to the following equation:

$$
R A W=p * T A W
$$

where $p$ is a fraction of $T A W$ which is available for the plant without reduction in $E T$ it was considered as 0.3 for pepper crop according to Allen et. al. (1998).

The leaching requirements $\left(L_{R}\right)$ for the experimental soil under pepper crop were estimated according to Ayers and Westcot, 1976 (FAO-29) as:

$$
L_{R}=E C_{i w} /\left(5 E C_{e}-E C_{i w}\right)
$$

$E C e=1.5 \times E C_{i w}$ under conditions where leaching fraction is $15-20 \%, E C_{i w}$ is the electrical conductivity of the irrigation water $\left(2.65 \mathrm{ds} \mathrm{m}^{-1}\right)$ and $L_{R}$ is $15.4 \%$. The applied irrigation depth $\left(I_{w}\right)$ in $\mathrm{mm}$ was calculated by the following equation: 


$$
I_{w}=\frac{R A W}{E_{i}\left(1-L_{R}\right)}
$$

where $I_{w}$ is the irrigation depth [mm] for the part of the surface that is wetted (35\%) and $E_{i}$ is the water application efficiency. Values for $E_{i}$ were 0.9 for surface drip irrigation system (SDI) and 0.95 for subsurface drip irrigation system (SSDI).

The irrigation intervals $(I I)$ in days were estimated the following equation:

$$
I I=\frac{R A W}{E T_{c}}
$$

\section{Water productivity $(W P)$ and nutrient use efficiency $(N U E)$}

Water productivity (WP) is defined, according to Molden et al. (2010), as the net benefit from the crop to the amount of water used to produce those benefits, i.e., the relationship between the marketable fruit yield $\left(\mathrm{kg} \mathrm{ha}^{-1}\right)$ and the total water applied $\left(\mathrm{m}^{3} \mathrm{ha}^{-1}\right)$ (Patanè et al., 2011).

Nutrient use efficiency (NUE) can be expressed several ways. Mosier et al. (2004) described 4 agronomic indices commonly used to describe nutrient use efficiency: partial factor productivity (PFP, kg crop yield per $\mathrm{kg}$ nutrient applied); agronomic efficiency (AE, kg crop yield increase per kg nutrient applied); apparent recovery efficiency (RE, kg nutrient taken up per kg nutrient applied); and physiological efficiency (PE, kg yield increase per kg nutrient taken up). Crop removal efficiency (removal of nutrient in harvested crop as $\%$ of nutrient applied) is also commonly used to explain nutrient efficiency.

According to FAO (2005), the pepper crop needs on average $250 \mathrm{~kg} \mathrm{ha}^{-1}$ of nitrogen fertilizer, $55 \mathrm{~kg} \mathrm{ha}^{-1}$ of phosphor fertilizer in form of $\mathrm{P}_{2} \mathrm{O}_{5}$ and $60 \mathrm{~kg} \mathrm{ha}{ }^{-1}$ potassium, in form of $\mathrm{K}_{2} \mathrm{O}$, which were applied in this experiment.

Under SDI and SSDI, the yield was measured considering all the plants under each 3 replicates of the three treatments.

\section{RESULTS AND DISCUSSION}

The relation between the estimated $E T_{o}$ values

The seasonal trend of $E T_{o}$ during the growth season estimated by using IM, ES and CW models, with daily data (IM) or historical records either from 
local records (ES) or national records for the area (CW), is displayed in Fig. (2). The predicted $E T_{o}$ values from ES was very close to the values obtained from IM especially from August to October. After October, the differences between both increases until the highest value at the end of season (November 30). The values of $E T_{o}$ estimated by $\mathrm{CW}$ were very different from IM line and also very different from ES model, except in August. These discrepancies are due to the differences between local meteorological data used and historical records in this particular year.

OIM + ES $\triangle \mathrm{CW}$

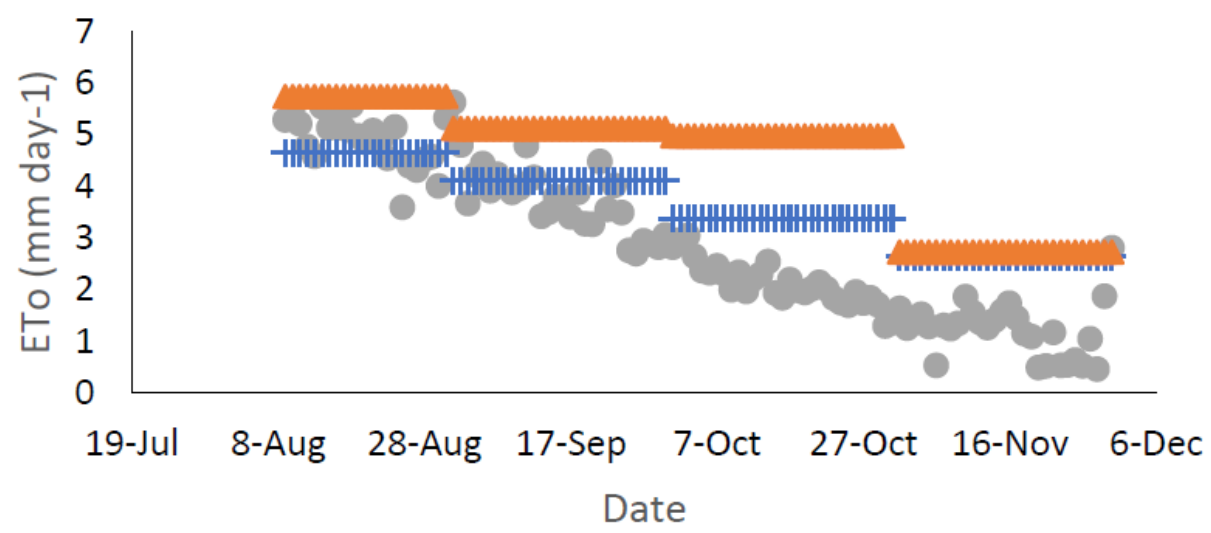

Fig (2). The relationship between estimated values of $E T_{o}$

\section{The relationship between the estimated crop coefficient $(K c)$}

The changes of Kc estimated by the different models (IM, ES and CW) during the growth season are illustrated in Fig. (3).

The lines of $E S$ and $I M$ were closed to each other by the middle season, from the start of mid stage (September, 24) until the end of season, while the $C W$ line was far from other lines. All lines started from the same point at the beginning of the season (initial growth stage) and crossed at the start of mid growth stage. 


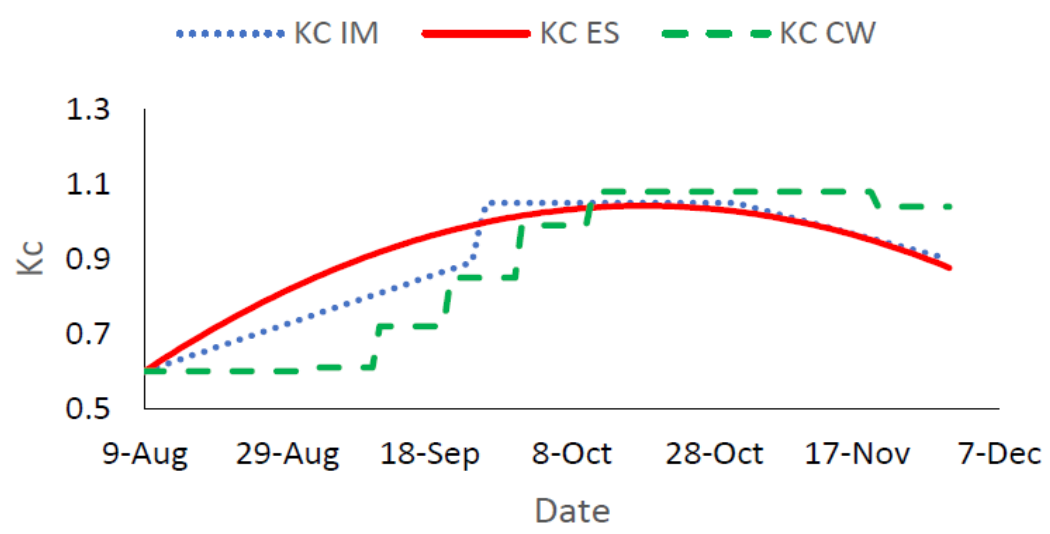

Fig (3). Relationship between estimated values of $K c$

\section{The relation between the estimated $E T c$ by different models}

The results of $E T_{C}$ for the three models are illustrated in Fig. (4) and are the consequence of the deviations displayed in Figures 2 and 3. All lines in the initial stage (August, 9 until September, 20) are very close but, after that, the distance among all lines increases until October, 31. The difference between IM and CW is $3.83 \mathrm{~mm}^{-1 a y}{ }^{-1}$ and between IM and ES is $1.55 \mathrm{~mm}$ day $^{-1}$. After October, these differences decreased until $0.88 \mathrm{~mm}_{\text {day }}{ }^{-1}$ and $1.4 \mathrm{~mm}^{-1}$ day $^{-1}$ between IM and ES and between IM and CW, respectively.

- etc IM $\square$ etc Es $\triangle$ etc CW

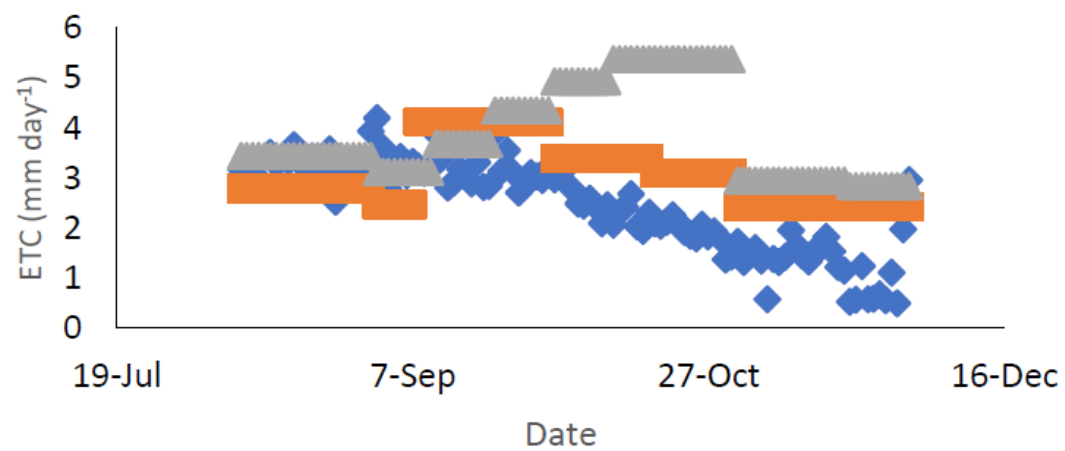

Fig (4). Relationship between the actual and estimated values of $E T_{C}$

From the previous results of $E T_{O}, K c$ and $E T_{C}$, it appears that the lowest differences among all estimated values were between $I M$ and $E S$.

Consequently, the best selection after $I M$ is to select $E S$ for estimating the values of $E T_{C}$ with suitable accuracy, quickly, easily and with less costs (as it was estimated from historical records). 
The estimated and measured root depth, $\mathrm{Zr}$

The Figures 5, 6 and 7 show the estimated and measured values of root depth in each corresponding plot, during the growth season of pepper. The best predicted values were that obtained from expert system (ES) followed by that from CropWAT (CW) program while, the IRRIMET (IM) program has estimated the root depth as a constant value $(35 \mathrm{~cm})$ from the beginning until harvest.

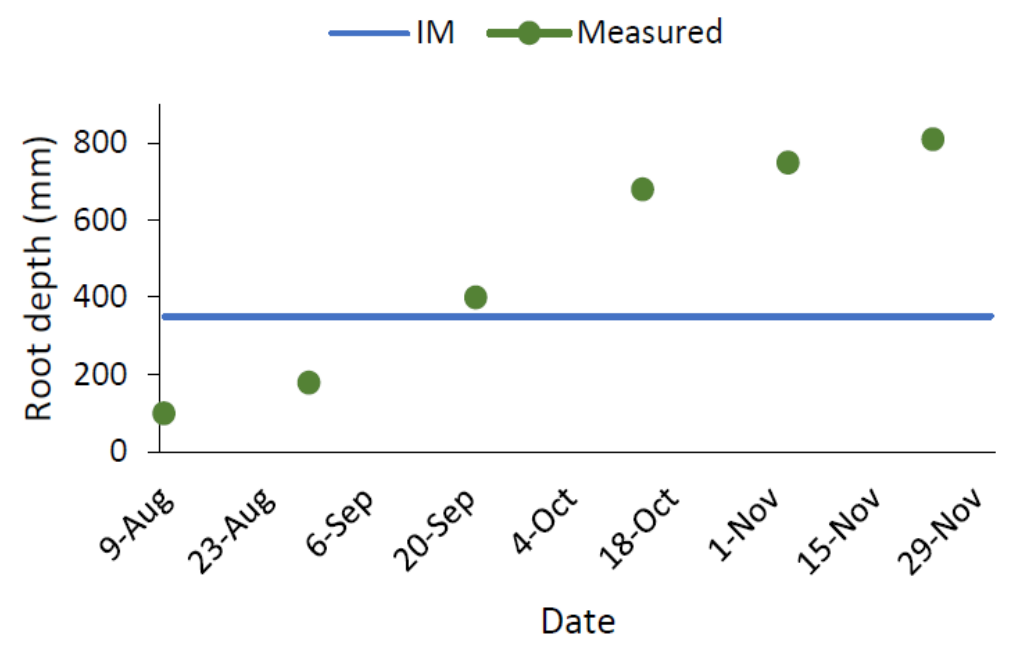

Fig (5). Estimated and measured root depth by IM in the corresponding plots $(\mathrm{n}=3)$ during the growth season.
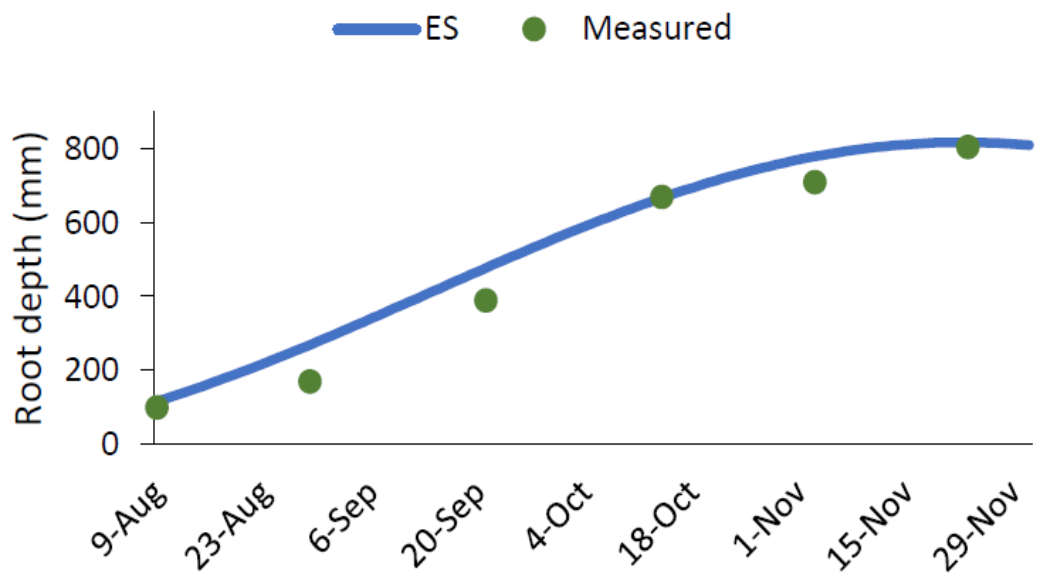

Fig (6). Estimated and measured root depth by ES in the corresponding plots $(n=3)$ during the growth season. 


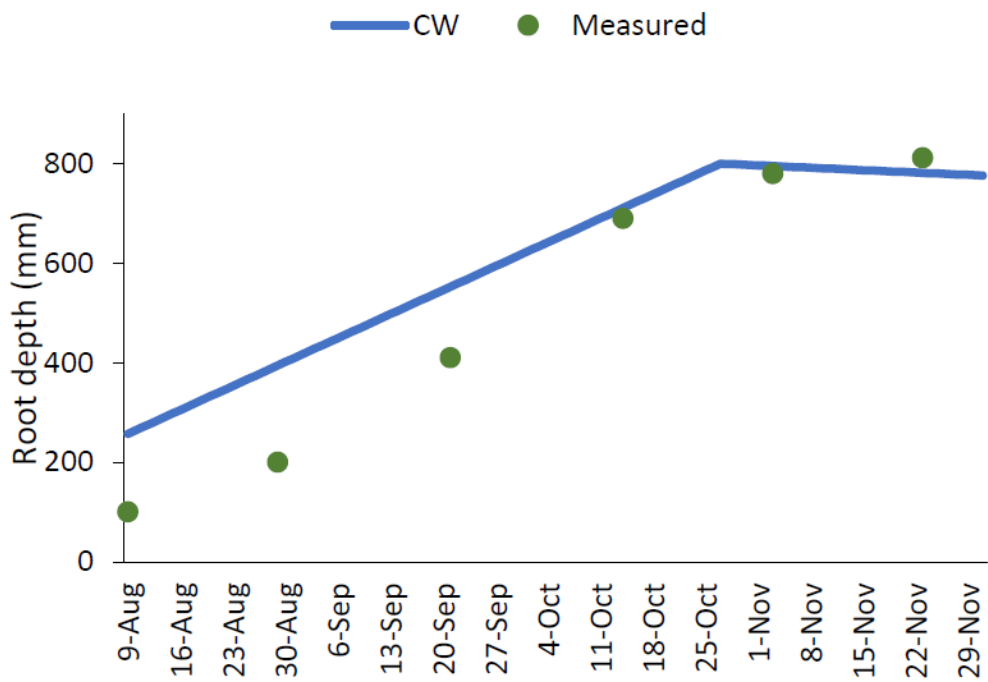

Fig (7). Estimated and measured root depth by $\mathrm{CW}$ in the corresponding plots $(n=3)$ during the growth season.

\section{Yield and water productivity (WP)}

Table (1) shows the yield and water productivity $W P$ of the pepper crop by using the three irrigation management models, under surface drip irrigation (SDI) and sub-surface drip irrigation (SSDI) systems.

$\underline{\text { Table (1). Yield and } W P \text { of pepper crop }}$

\begin{tabular}{|c|c|c|c|c|c|c|c|c|c|}
\hline \multirow[b]{2}{*}{$\begin{array}{c}\text { Irrigation } \\
\text { system (IS) }\end{array}$} & \multirow{2}{*}{ 寻急 } & \multicolumn{4}{|c|}{ Yield (ton $\mathrm{h}^{-1}$ ) } & \multicolumn{4}{|c|}{$W P\left(\mathrm{~kg} \mathrm{~m}^{-3}\right)$} \\
\hline & & 2016 & 2017 & 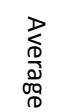 & $\%$ & 2016 & 2017 & 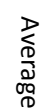 & $\%$ \\
\hline \multirow{3}{*}{ SSDI } & IM & 16.32 & 13.71 & 15.0 & 100 & 3.78 & 1.05 & 2.4 & 100 \\
\hline & ES & 13.33 & 13.14 & 13.2 & 88.1 & 3.09 & 1.12 & 2.1 & 87.2 \\
\hline & CW & 11.45 & 11.62 & 11.5 & 76.8 & 2.65 & 0.805 & 1.7 & 71.5 \\
\hline \multirow{3}{*}{ SDI } & IM & 16 & 10 & 13.0 & 100 & 3.9 & 0.77 & 2.3 & 100 \\
\hline & ES & 10.61 & 9.62 & 10.1 & 67.4 & 2.59 & 0.805 & 1.7 & 72.7 \\
\hline & CW & 6.5 & 6.38 & 6.4 & 42.9 & 1.58 & 0.595 & 1.1 & 46.6 \\
\hline
\end{tabular}

Data illustrated in Table (1) reveal that SDI resulted in lower yields of pepper than the corresponding ones achieved due to the SSDI; not only the yields are lower but the SDI consumed a higher quantity (by $5 \%$ ) of irrigation water (data not shown) than the SSDI irrigation, both factors contributing to higher WP with SSDI. 
Table (2). NUE for pepper crop

\begin{tabular}{|c|c|c|c|c|c|c|c|c|c|c|}
\hline \multirow{3}{*}{$\begin{array}{c}\text { Irrigation } \\
\text { system }\end{array}$} & \multirow{3}{*}{ Treatment } & \multicolumn{9}{|c|}{$N U E\left(\mathrm{~kg} \mathrm{~kg}^{-1}\right)$} \\
\hline & & \multicolumn{4}{|c|}{2016} & \multicolumn{4}{|c|}{2017} & \multirow{2}{*}{$\begin{array}{c}\text { Average } \\
\text { Total } \\
\text { (NPK) }\end{array}$} \\
\hline & & $\mathbf{N}$ & $\mathbf{P}$ & $\mathbf{K}$ & $\begin{array}{l}\text { Total } \\
\text { (NPK) }\end{array}$ & $\mathbf{N}$ & $\mathbf{P}$ & $\mathbf{K}$ & $\begin{array}{c}\text { Total } \\
\text { (NPK) }\end{array}$ & \\
\hline \multirow{3}{*}{ SSDI } & IM & 65.3 & 679.1 & 327.8 & 50.4 & 54.9 & 570.6 & 275.4 & 42.4 & 46.4 \\
\hline & ES & 53.3 & 554.4 & 267.6 & 41.2 & 52.6 & 546.8 & 263.9 & 40.6 & 40.9 \\
\hline & CW & 45.8 & 476.2 & 229.8 & 35.3 & 46.5 & 483.4 & 233.3 & 35.9 & 35.6 \\
\hline \multirow{3}{*}{ SDI } & IM & 64.0 & 665.7 & 321.3 & 49.4 & 40.0 & 416.1 & 200.8 & 30.9 & 40.1 \\
\hline & ES & 42.4 & 441.5 & 213.1 & 32.8 & 38.5 & 400.2 & 193.2 & 29.7 & 31.2 \\
\hline & CW & 26.0 & 270.4 & 130.5 & 20.1 & 25.5 & 265.5 & 128.1 & 19.7 & 19.9 \\
\hline
\end{tabular}

The highest average values of yields of season 2016 and 2017 were achieved with the IM model, i.e., 15 and 13 ton $\mathrm{h}^{-1}$, under SSDI and SDI systems, respectively, followed by ES, which gave a yield not far away from those resulting from IM, i.e. 13.2 and 10.1 ton $\mathrm{h}^{-1}$, under SSDI and SDI, respectively. CW resulted in the lowest yields, i.e. 11.5 and 6.4 ton $\mathrm{h}$. ${ }^{1}$ under SSDI and SDI, respectively.

Also, the results in table (1) show WP under the different irrigation management models (IM, ES and CW) under surface (SDI) and subsurface drip irrigation systems (SSDI). The highest values of WP were obtained with IM, i.e. 2.4 and $2.3 \mathrm{~kg} \mathrm{~m}^{-3}$ under SDI and SSDI, respectively, followed by ES, i.e. 2.1 and $1.7 \mathrm{~kg} \mathrm{~m}^{-3}$ under SSDI and SDI, respectively. The lowest $W P$ was with $\mathrm{CW}$, i.e. 1.7 and $1.1 \mathrm{~kg} \mathrm{~m}^{-3}$, respectively.

Table (2) shows the effects of the irrigation management model (IM, ES and $\mathrm{CW}$ ) under the two investigated irrigation systems, SDI and SSDI on nutrient use efficiency (NUE) of pepper crop. The highest average values of $N U E$ were found by using the IM model, i.e. $46.4 \mathrm{~kg} / \mathrm{kg}$ and $40.1 \mathrm{~kg} / \mathrm{kg}$ under SSDI and SDI systems, followed by ES method $(40.9 \mathrm{~kg} / \mathrm{kg}$ and 31.2 $\mathrm{kg} / \mathrm{kg}$ ), respectively. And the lowest values were achieved by CW (35.6 $\mathrm{kg} / \mathrm{kg}$ and $19.9 \mathrm{~kg} / \mathrm{kg}$ ) under the SSDI and SDI, respectively.

These results show that, using the ES model for irrigation management of pepper resulted in $W P$ and $N U E$ values not very far from those achieved using the IM model. However, using the expert system $(E S)$ model had less costs due to the original data required in this case so it seems to be the best compromise between costs of applying the model and benefit.

\section{CONCLUSION}

The aim of this study was to select the cheapest and most accurate management irrigation model between three irrigation management models under surface and subsurface drip irrigation systems, where differences 
were mainly due to original data used. The results showed that the highest water savings were achieved by IM followed by ES model. Also, the estimated values of $E T_{o}, K c$ and $E T_{C}$ under ES were very close to the corresponding values by IM, while for $\mathrm{CW}$, values were far from IM values especially for $E T_{C}$. Moreover, the highest values of yield were generally achieved under subsurface drip irrigation system (SSDI). On the other hand, the IM model gave the highest values of yield, NUE and WP (15 ton $\mathrm{ha}^{-1}, 46.4 \mathrm{~kg} / \mathrm{kg}$ and $2.4 \mathrm{~kg} \mathrm{~m}^{-3}$, respectively under SSDI), followed by ES (13.2 ton ha ${ }^{-1}, 40.9 \mathrm{~kg} / \mathrm{kg}$ and $2.3 \mathrm{~kg} \mathrm{~m}^{-3}$, respectively under SSDI) while the lowest values of yield $N U E$ and $W P$ were achieved with the CW model. Finally, it could be recommended that the ES model to be an accepted tool for water management.

\section{ACKNOWLEDGMENT}

The author thanks ASRT for supporting this study, which carried out under the project of "Water Saving in Agriculture: technological developments for the sustainable management of limited water resources in the Mediterranean area".

\section{REFERENCES}

Allen, R. G., Pereira, L. S., Raes, D., and Smith, M. (1998). Crop evapotranspiration - Food and Agriculture Organization. Food and Agriculture Organization of the United Nations.

Al-Najar, H. (2011). The Integration of FAO-CropWat Model and GIS Techniques for Estimating Irrigation Water Requirement and Its Application in the Gaza Strip.

Ayers, R.S. and Westcot, D.W. (1976). Water quality for agriculture. FAO Irrigation and Drainage Paper 29, Rome.

Borg, H., and D.W. Grimes. 1986. Depth development of roots with time: An empirical description. Trans. ASAE 29:194-197

Bryla, D. R., Trout, T. J., and Ayars, J. E. (2010). Weighing Lysimeters for Developing Crop Coefficients and Efficient Irrigation Practices for Vegetable Crops. Hortscience, 45(11), 1597-1604.

Domínguez, Á. M., and Sainz-Aguirre, J. M. (2016). Manual de Usuario de WikiUCA. Retrieved 12 17, 2018.

Brouwer, C., and Heibloem, M. (1986). Irrigation water management: Irrigation water needs, Training Manual no. 3 (Chapter 3), Food and Agriculture Organization (FAO), Rome, Italy. 
FAO (2005). Fertilizer use by crop in Egypt. Rome, Italy.

Farag, A. A., (2012). Fertigation technique management based on expert system. Thesis, Faculty of Agriculture, Benha University, Egypt.

Gohar, A. A., and Ward, F. A. (2013). Mitigating impacts of water shortage on Egyptian agriculture: a catchment scale analysis. Water Policy, 15(5), 738-760.

Granados, M. R., Thompson, R., Fernández, M., Martínez-Gaitán, C., and Gallardo, M. (2013). Prescriptive-corrective nitrogen and irrigation management of fertigated and drip-irrigated vegetable crops using modeling and monitoring approaches. Agricultural Water Management, 119, 121-134.

Grosan, C., and Abraham, A. (2011). Rule-Based Expert Systems.

Köppen, W. (1936). Das geographische System der Klimate, in: Handbuch der Klimatologie, Band 1, Teil C., edited by: Köppen, W. and Geiger, R., Gebr. Borntraeger, Berlin, 1-44, 1936.

Molden D, Oweis T, Steduto P, Bindraban P, Hanjra MA and Kijne J (2010). Improving agricultural water productivity: Between optimism and caution. Agric Water Manage 97: 528-535.

Mosier, A. R., Syers, J. K. and Freney, J. R. (2004). Agriculture and the Nitrogen Cycle. Assessing the Impacts of Fertilizer Use on Food Production and the Environment. Scope-65. Island Press, London.

Patanè, C., Tringali, S. and Sortino, O. (2011). Effects of deficit irrigation on bio-mass, yield, water productivity and fruit quality of processing tomato under semi-arid Mediterranean climate conditions. Sci Hortic 129: 590-596.

Mundo, M., Martinez, P., Mireles, V. and Zazueta, F. (1970). Expert systems for water management in irrigation districts. WIT transactions on information and Communication Technologies, 10.

Seleym, A., and Elshafei, M. (2017). Potential of Solar-driven CDI Technology for Water Desalination in Egypt.

Smith, M. (1992). CROPWAT-A computer program for irrigation planning and management. In FAO Irrigation and Drainage Paper; FAO Land and Water Development Division: Rome, Italy, 1992adapt format). 
Walters, S. A., and Jha, A. K. (2016). Sustaining Chili Pepper Production in Afghanistan through Better Irrigation Practices and Management. Agriculture, 6(4), 1-10.

Zayed, M. S., Hassanein, M. K., Esa, N. H. and Abdallah, M. (2013). Productivity of pepper crop (Capsicum annuum L.) as affected by organic fertilizer, soil solarization, and endomycorrhizae. Annals of Agricultural Sciences, 58(2), 131-137.

\section{الملخص العربي}

إدارة الري لمحصول الفلقل تحت نظامي الري بالتقيط السطحي وتحت السطحي

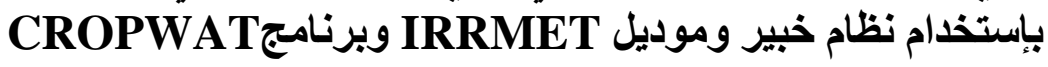

$$
\text { أبوسريع أ. فرجن }
$$

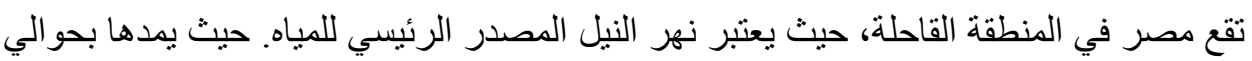

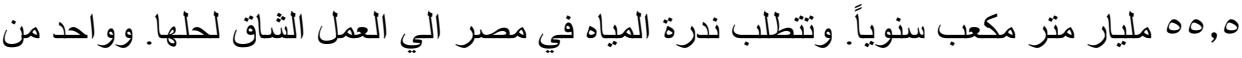

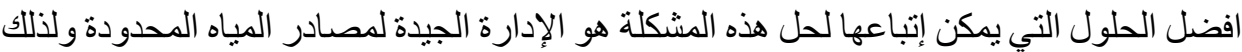

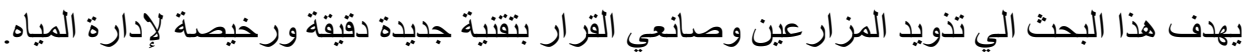

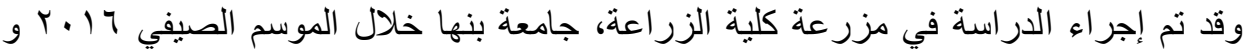

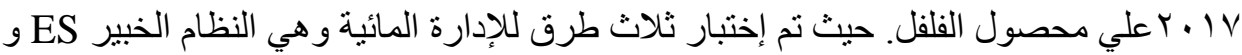
الموديل Cropwat (CW) وكيث تم إختبار ها تحت نظامي الري

$$
\text { وقالتنقيط فوق السطحي وتحت سطحي. }
$$

ـ ـ أعلى كمية المياه تم توفير ها كان مع إستخدام نظام IM يليها النظام الخبير وقد أنى ال

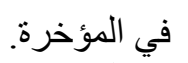

ـ ـ أيضاً كانت قيم البخرنتح المرجعي و المعامل المحصولي والإستهلاك المائي المحسوبة و المنوقعة بالنظام الخبير قريبة جدا من القيم المقاسة بإستخدام IM بينما كانت القيم المحسوبة

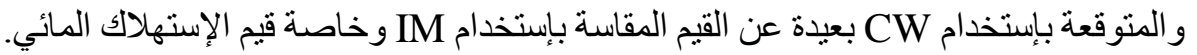

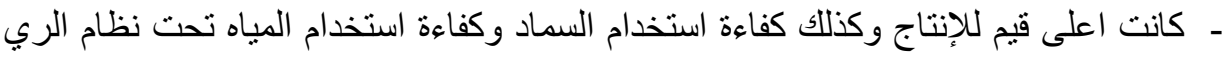
بالتنقيط تحت سطح التربة التباج - اعطى اعلي انتاج وكذلك اعلي كفاءة استخدام للمياه و السماد يليها النظام الخبير بدون اي

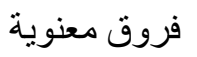

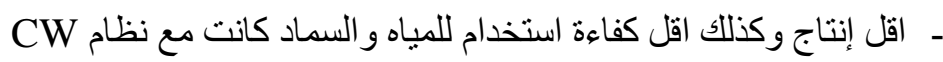
ومن النتائج السابق ذكر ها يمكن ان نرشح هذا النظام الخبيرليكون أداة جيدة للإدارة المياه وذلك لترشيد إستخدام المياه وكذلك السماد.

* مدرس بقسم هندسة النظم الزراعية والحيوية، كلية الزراعة جامعة بنها، مصر. 